Vol. 7 , No 1, Januari $2021,030-0$.

\title{
PENGARUH SUASANA TOKO TERHADAP KEPUTUSAN PEMBELIAN KONSUMEN PADA MR.DAV COFFEE SHOP PALU
}

\author{
Indasari \\ Syamsul Bachri \\ Program Studi S1 Jurusan Manajemen, Fakultas Ekonomi dan Bisnis, Universitas Tadulako \\ Email: indahlamatupuang@gmail.com;syamsulbachri09@gmail.com
}

\begin{abstract}
The purpose of this study is to determine the effect of the store atmosphere on consumer purchasing decisions on Mr. Dav Coffee Shop Samples were taken as many as 50 respondents using the accidental sampling method. The results of this study note that the atmosphere of the store which includes: (1) Store atmosphere has a positive effect on consumer purchasing decisions with a significance level of 0,000. (2) The outside of the store has a positive effect on consumer purchasing decisions with a significance level of 0.589. (3) General interior has a positive effect on consumer purchasing decisions with a significance level of 0.004. (4) Store layout has a positive effect on consumer purchasing decisions with a significance level of 0.048. (5) Interior display has a positive effect on consumer purchasing decisions with a significance level of 0.015. The magnitude of the influence of the store atmosphere on consumer purchasing decisions (adjusted R2) was 54.3\%.
\end{abstract}

Keywords: Store Atmosphere, Store Exterior, General Interior, Store Layout, Interior Display, Purchase Decision.

\begin{abstract}
ABSTRAK
Penelitian ini bertujuan untuk mengetahui pengaruh suasana toko terhadap keputusan pembelian konsumen pada Mr. Dav Coffee Shop. Sampel yang diambil sebanyak 50 responden dengan menggunakan metode accidental sampling.Adapun hasil dari penelitian ini diketahui bahwa suasana toko yang meliputi: (1) Suasana Toko berpengaruh positif terhadap keputusan pembelian konsumen dengan tingkat signifikansi sebesar 0.000. (2) Bagian luar toko berpengaruh positif terhadap keputusan pembelian konsumen dengan tingkat signifikansi sebesar 0.589. (3) Interior umum berpengaruh positif terhadap keputusan pembelian konsumen dengan tingkat signifikansi sebesar 0.004. (4) Tata letak toko berpengaruh positif terhadap keputusan pembelian konsumen dengan tingkat signifikansi sebesar 0.048. (5) Pajangan interior berpengaruh positif terhadap keputusan pembelian konsumen dengan tingkat signifikansi sebesar 0.015 . Besarnya pengaruh suasana toko terhadap keputusan pembelian konsumen (adjusted $\mathrm{R}^{2}$ ) adalah sebesar 54,3\%.
\end{abstract}

Kata Kunci: Suasana Toko, Bagian Luar Toko, Interior Umum, Tata Letak Toko, Pajangan Interior, Keputusan Pembelian.

\section{PENDAHULUAN}

Bisnis kuliner masa ini banyak dibuka di beberapa kota di Indonesia salah satunya di Kota Palu. Tersedia berbagai macam jenis bisnis kuliner antara lain depot, restoran, rumah makan, kafe serta kedai. Diantara berbagai macam jenis bisnis kuliner yang banyak digeluti para pelaku bisnis saat ini di Kota Palu yaitu bisnis restoran bertipe kafe. Saat ini banyak terdapat kafe-kafe, namun perubahan life style dan cara untuk menikmati serta mengkonsumsi makanan serta minuman bagi masyarakat saat ini, dapat membawa beberapa inovasi baru terkait kafe yang dianggap lebih diminati oleh para konsumen.

Saat ini kafe bukan saja dijadikan sebagai tempat makan, melainkan sebagai tempat berkumpul maupun bersantai dalam waktu yang sangat lama dan tak jarang juga dijadikan sebagai tempat para mahasiswa mengerjakan tugas kuliahnya. Hal tersebut menyebabkan para pelaku bisnis semakin bersemangat untuk membangun bisnis kafe. Pelaku bisnis kafe harus bisa menggunakan strategi 
Vol. 7, No 1, Januari 2021, 030-038

pemasaran yang tepat agar mampu bertahan dalam bersaing pada bisnis kafe yang lainnya sehingga dapat menarik minat konsumen untuk mendatangi kafe tersebut.

Dimulai pada akhir tahun 2014 hingga saat ini banyak masyarakat mengunjungi sebuah kafe tidak hanya untuk menikmati menu yang tersedia pada kafe tersebut tetapi tak jarang pula mereka mengabadikan momen disana dan mengunggahnya di media sosial. Maka secara tidak langsung, saat pertama kali mendatangi sebuah kafe maka konsumen bisa langsung memberikan penilaian terhadap suasana dari kafe tersebut. Sehingga suasana dari kafe tersebut akan langsung mempengaruhi perasaan dari konsumen tersebut.

Sebagian orang akan menghabiskan waktu mereka disebuah kafe. Dengan menciptakan suasana kafe yang nyaman, menarik dan berbeda dari kafe-kafe lainnya untuk mempengaruhi proses keputusan konsumen untuk berkunjung pada sebuah kafe. Suasana kafe yang nyaman dapat membuat para konsumen menjadi ingin berlama-lama dan menghabiskan waktu sehingga hal tersebut juga dapat meningkatkan jumlah pengunjung pada kafe tersebut.

Hal tersebut yang menyebabkan suatu kafe seperti coffee shop tidak hanya menyediakan makanan ataupun minuman, tetapi juga menampilkan sesuatu yang lebih yang dapat dinikmati setiap pengunjung kafe, misalnya penataan ruangan dikafe, hiasan ruangan kafe dan penataan lampu. Ada juga yang menampilkan beberapa hiburan seperti penampilan musik atau acara nonton bareng pertandingan sepak bola hanya untuk menarik konsumen untuk berkunjung pada kafe tersebut.

Dari beberapa pilihan kafe yang ada saat ini, ada beberapa hal penting yang merupakan alasan konsumen memilih suatu kafe. Setiap konsumen mempunyai ekspektasi berbeda-beda. Ekspektasi yang dimiliki konsumen belum tentu dapat membuat konsumen tersebut untuk melakukan pembelian pada suatu kafe. Harapan tersebut harus dapat didorong sehingga dapat memunculkan keinginan untuk melakukan pembelian. Terdapat berbagai macam faktor yang dapat menjadi pendorong, salah satunya adalah suasana toko. Dengan kata lain, suasana toko dapat mempengaruhi minat dari para konsumen yang berkunjung sehingga meningkatkan stimulus mereka untuk melakukan keputusan pembelian pada suatu kafe.

Menurut Levy dan Weitz dalam Valentine (2012: 613) suasana toko adalah gabungan dari ciri toko (seperti arsitektur, tata letak, tanda-tanda dan displays, warna, pencahayaan, suhu, suara dan bau), yang bersama-sama membuat gambar dalam pikiran konsumen. Menurut Kotler dan Armstrong (2001: 226) keputusan pembelian adalah mekanisme pengambilan keputusan yang dimana saat itu konsumen tersebut telah melakukan pembelian

\section{KAJIAN LITERATUR DAN PENGEMBANGAN HIPOTESIS}

Pemasaran

Menurut Kotler dan Armstrong (2001: 7-8) pemasaran sebagai proses sosial dan manajerial yang membuat individu serta kelompok mendapatkan sesuai kebutuhan dan keinginan.

\section{Manajemen Pemasaran}

Menurut Kotler dan Keller (2016: 17) manajemen pemasaran adalah teks pemasaran terkemuka karena konten dan organisasinya secara konsisten mencerminkan perubahan dalam teori dan praktik pemasaran.

\section{Pengertian Kafe}

Kafe dari (bahasa Perancis: café) secara harfiah adalah (minuman) kopi, namun saat ini menjadi tempat untuk makan dan minum yang bukan hanya kopi. Di Indonesia, kafe semacam tempat sederhana, tetapi menarik. Dengan ini kafe berbeda dibandingkan warung.

\section{Suasana Toko}

Suasana toko adalah suasanaterencana yang sesuai dengan sasaran pasar sehingga memungkinkan dapat menarik minat konsumen untuk berkunjung.

Menurut Berman dan Evans (2010: 508), atmosfer mengacu pada ciri fisik sebuah kafe yang dapat menarik pelanggan. Adapun elemen-elemen menurut Berman dan Evans (2010) dibagi menjadi empat elemen, yaitu:

\section{a. Bagian Luar Toko}


Vol. 7, No 1, Januari 2021, 030-038

Bagian luar toko terdiri dari berpengaruh kuat pada citra sebuah toko sehingga harus terencana. Gabungan dari bagian luar toko ini dapat membuat menjadi terlihat unik, menarik, serta dapat mengundang orang untuk masuk ke dalam kafe. Bagian luar toko terdiri dari: bagian depan toko, papan nama toko, pintu masuk toko, toko dan area sekitarnya dan fasilitas tempat parkir.

b. Interior Umum

Ketika kosumen berada di dalam toko, ada beberapa elemen yang akan mempengaruhi persepsi konsumen, sehingga harus dirancang serta ditata dengan sangat tepat. Sub elemen dalam interior umum yaitu: jenis lantai, warna dan pencahayaan, aroma dan musik, tekstur dinding, suhu udara, lorong ruangan, karyawan toko, akses mobilitas antar lantai, teknologi dan kebersihan.

c. Tata Letak Toko

Tata letak toko adalah suatu rencana tertentu untuk menentukan tata letak fasilitas sebuah toko. Sub elemen dalam tata letak toko yaitu: penataan penempatan ruang untuk mengisi lantai yang tersedia, penempatan ruang untuk memudahkan konsumen berinteraksi dengan karyawan seperti meja kasir dan penempatan fasilitas toko seperti tata letak kursi ataupun tata letak meja.

d. Pajangan Interior

Tujuan dari pajangan interior ini adalah untuk meningkatkan penjualan dan keuntungan suatu toko. Sub elemen dalam pajangan interior yaitu: tampilan poster, tanda petunjuk lokasi dan pajangan dalam toko.

\section{Keputusan Pembelian Konsumen}

Kotler dan Armstrong (2001: 226) mendefinisikan keputusan pembelian konsumen adalah membeli suatu produk yang paling dibutuhkan dan diiginkan, tetapi ada faktor akan muncul antara niat untuk membeli serta keputusan pembelian.Proses keputusan pembelian terdiri dari lima tahap, yaitu:

a. Pengenalan Kebutuhan

b. Pencarian Informasi

c. Evaluasi Alternatif

d. Keputusan Pembelian

e. Perilaku Pasca Pembelian

\section{Hubungan antara Suasana Toko dengan Keputusan Pembelian}

Beberapa kafe menerapkan suasana toko sebagai strategi utama dalam pemasarannya. Hal tersebut terjadi karena suasana toko mampu memberikan efek pada perilaku konsumen dan menarik minat konsumen untuk melakukan pembelian pada kafe tersebut. Suasana toko dapat menciptakan respon yang berbeda-beda bagi setiap konsumen.Menciptakan suasana toko yang baik diyakini dapat menjadi strategi yang tepat bagi suatu kafe dalam bersaing dengan kafe-kafe lain. Penciptaan suasana toko harus memberikan suasana yang nyaman, unik, serta berbeda dari kafe lainnya. Hal tersebut agar dapat menarik konsumen untuk berkunjung dan melakukan pembelian pada kafe tersebut.

\section{METODE PENELITIAN}

Jenis penelitian yang digunakan dalam penelitian ini adalah deskriptif kausal yang artinya di lakukan untuk memperoleh gambaran tentang penelitian yang berkaitan dengan pengaruh suasana toko terhadap keputusan pembelian konsumen pada Mr. DavCoffee Shop Palu. Objek penelitian ini yaitu pengaruh suasana tokoterhadap keputusan pembelian konsumen. Sedangkan subjek penelitian ini yaitu konsumen pada Mr. DavCoffee Shop Palu. Adapun jenis data yang digunakan penelitian ini yaitu data kuantitatif yang akan diolah dari hasil kuesioner yang akan dibagikan kepada konsumen Mr. Dav Coffee Shop Palu. Populasi dalam penelitian ini jumlahnya tidak dapat diketahui. Adapun yang akan menjadi sampel dalam penelitian ini harus berdasarkan karakteristik yaitu sebagai berikut :

a. Pernah berkunjung ke Mr. Dav Coffee Shop Palu

b. Berusia 17 tahun keatas

Menurut Roscoe (Research Methods For Business) dalam Kurniawan (2014: 85) ada beberapa saran tentang penentuan ukuran sampel untuk penelitian yaitu bila dalam penelitian akan menggunakan alat analisis multivarian, maka jumlah anggota sampel minimal 10 kali dari jumlah 
Vol. 7, No 1, Januari 2021, 030-038

variabel yang diteliti. Misalnya variabel penelitian terdiri dari 5 variabel (4 variabel independen +1 variabel dependen), maka jumlah anggota sampel $=10 \times 5$ variabel (bagian luar kafe, interior umum, tata letak kafe, dan pajangan interior dan Keputusan Pembelian Konsumen) $=50$ orang/responden. Teknik pengambilan sampel dalam penelitian ini adalah Non Probability Sampling, karena populasi yang diteliti infinite (populasi yang jumlah dan identitas anggota populasi tidak diketahui). Salah satu teknik penarikan sampel dalam kelompok Non Probability Sampling adalah Accidental Sampling.

\section{Uji Asumsi Klasik}

\section{Uji Normalitas}

Uji nomalitas digunakan untuk menguji apakah dalam sebuah model regresi variabel dependen dan variabel independen atau keduanya memiliki distribusi normal (Ghozali, 2013: 160). Model regresi yang baik adalah distribusi data normal atau mendekati normal. Deteksi normalitas dilakukan dengan melihat penyebaran data (titik) pada sumbu diagonal dari grafik. Dasar pengambilan keputusannya yaitu:

1. Jika data tersebar disekitar garis diagonal dan mengikuti arah garis diagonal, maka model regresi memenuhi asumsi normalitas.

2. Jika data menyebar jauh dari garis diagonal atau tidak mengikuti arah garis diagonal, maka model regresi tidak memenuhi asumsi normalitas.

\section{Uji Multikolinearitas}

Uji Multikolinearitas digunakan untuk menguji apakah model regresi ditemukan adanya korelasi antara variabel bebas independen. Model regresi yang baik seharusnya antara variabel independen terjadi korelasi antara variabel dependen (Ghozali, 2013: 105). Uji multikolinearitas dapat dilakukan dengan dua cara yaitu dengan melihat:

1. Nilai tolerance dan lawannya.

2. VIF (Varlance Inflation Faktors). Jika tolerance $\leq 0,10$ atau sama dengan nilai VIF $\geq 10$ maka menunjukkan adanya multikolinearitas, dan sebaliknya (Ghozali, 2013: 105-106).

\section{Uji Heteroskedastisitas}

Uji heteroskedastisitas bertujuan untuk menguji apakah dalam model regresi terjadi ketidaksamaan varian dari residual satu pengamatan dengan yang lainnya. Gejala yang tidak sama ini disebut dengan heteroskedastisitas, sedangkan adanya gejala residual yang sama dari satu pengamatan dengan yang lainnya disebut dengan homoskedastisitas. Untuk mendeteksi heteroskedastisitas yaitu dengan melihat pola tertentu pada grafik dimana sumbu $\mathrm{X}$ adalah $\mathrm{Y}$ yang telah diprediksi, dan sumbu $\mathrm{X}$ adalah residual (Y prediksi - Y sesungguhnya) yang telah di studientized. Maka dasar pengambilan keputusan:

1. Jika terdapat pola tertentu, seperti titik-titik (point-point) yang ada membentuk suatu pola tertentu yang teratur maka telah terjadi Heteroskedastisitas.

2. Jika tidak terdapat pola yang jelas, serta titik-titik menyebar di atas dan di bawah angka 0 pada sumbu Y, maka tidak terjadi Heteroskedastisitas.

\section{Analisis Regresi Berganda}

Untuk mengukur dan menganalisis besarnya pengaruh suasana toko terhadap keputusan pembelian konsumen di Mr. Dav Coffee Shop Palu, menggunakan alat analisis statistic parametric regresi linear berganda (Multiple Regression Analysis). Bentuk formulasi alat analisis statistik Regresi Linear Berganda secara matematis dapat dijabarkan sebagai berikut (Sugiyono, 2013: 277):

$$
Y=a+b_{1} X_{1}+b_{2} X_{2}+b_{3} X_{3}+b_{4} X_{4}+e
$$

Keterangan:

a

Y

$\mathrm{b}_{1}, \mathrm{~b}_{2}, \mathrm{~b}_{3}, \mathrm{~b}_{4}=$ Koefisien Regresi masing-masing Variabel

$\mathrm{X}_{1}$

$\mathrm{X}_{2}$
$=$ Konstanta

$=$ Keputusan Pembelian Konsumen

$=$ Bagian Luar Kafe

$=$ Interior Umum 


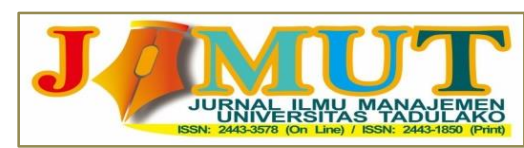

\begin{tabular}{ll} 
Vol. 7, No 1, Januari 2021, 030-038 \\
\hline $\mathrm{X}_{3}$ & $=$ Tata Letak Kafe \\
$\mathrm{X}_{4}$ & $=$ Pajangan Interior \\
$\mathrm{E}$ & $=$ Error/residu
\end{tabular}

\section{Pengujian Hipotesis}

\section{Pengujian Hipotesis Pertama (Uji Simultan/Uji F)}

Uji ini digunakan untuk mengetahui seluruh variabel independen secara bersama-sama mempunyai pengaruh yang signifikan terhadap variabel dependen. Sugiyono (2013), untuk mengetahui pengaruh signifikan atau tidak pengaruh secara bersama-sama variabel bebas terhadap variabel terikat pada tingkat kepercayaan sebesar 95\% $(\alpha=0,05)$. Yaitu dengan ketentuan sebagai berikut:

1. Jika sig $>\alpha(0,05)$, maka terbukti bahwa semua variabel bebas yang diteliti berpengaruh tidak signifikan terhadap variabel terikat.

2. Jika sig $<\alpha(0,05)$, maka terbukti bahwa semua variabel bebas yang diteliti berpengaruh signifikan terhadap variabel terikat.

\section{Pengujian Hipotesis Kedua - Kelima (Uji Parsial/Uji t)}

Pengujian hipotesis secara parsial dilakukan menggunakan uji t. Menurut Purwanto (2017: 193), uji terhadap nilai statistik t merupakan uji signifikansi parameter individual. Nilai statistik $t$ menunjukkan seberapa jauh pengaruh variabel independen secara individual terhadap variabel dependennya. Secara bebas dengan taraf signifikan sebesar 0,05 . Caranya dengan melakukan perbandingan antara $t_{\text {hitung }}$ dengan $t_{\text {tabel }}$ pada tingkat signifikan sebesar $\alpha=0,05$ dengan pedoman sebagai berikut (Sugiyono 2014)

1. Jika nilai signifikan (sig. t) $<\alpha=0,05$, artinya masing-masing variabel independen secara parsial berpengaruh signifikan terhadap keputusan pembelian konsumen. Dengan demikian hipotesis yang diajukan penelitian ini diterima secara parsial.

2. Jika nilai signifikan (sig. t) $>\alpha=0,05$, hal ini artinya masing-masing variabel independen secara parsial berpengaruh tidak signifikan terhadap keputusan pembelian konsumen. Dengan demikian dapat dinyatakan hipotesis yang diajukan penelitian ini masing-masing ditolak secara parsial.

\section{HASIL DAN PEMBAHASAN \\ Identitas Responden}

Responden yang berusia 17-25 tahun berjumlah 48orang atau 96\%, yang berusia 26-30 tahun berjumlah 1 orang atau $2 \%$ dan responden yang berusia $>40$ tahun berjumlah 1 orang atau $2 \%$. Responden yang berjenis kelamin laki-laki berjumlah 17 orang atau $34 \%$ dan yang berjenis kelamin perempuan berjumlah 33 orang atau $66 \%$. Kemudian responden yang memiliki penghasilan $<$ Rp. 1.000.000 berjumlah 30 orang atau 60\%, yang memiliki penghasilan Rp.1.000.000-Rp2.000.000 berjumlah 12 orang atau 24\%, yang memiliki penghasilan Rp.3.000.000 - Rp.4.000.000 berjumlah 6 orang atau $12 \%$ dan yang memiliki penghasilan $>$ Rp.5.000.000 berjumlah 2 orang atau 4\%. Diikut dengan responden seorang mahasiswa sebanyak 34 orang atau $68 \%$, responden yang bekerja sebagai karyawan swasta berjumlah 8 orang atau 16\%, responden yang bekerja sebagai wiraswasta berjumlah 5 orang atau $10 \%$ dan responden lainnya berjumlah 3 orang atau $6 \%$. Sedangkan responden berdasarkan jumlah kunjungan sebanyak 1 kali berjumlah 12 orang atau 24\%, responden berdasarkan jumlah kunjungan sebanyak 2-3 kali berjumlah 18 orang atau 36\%, responden berdasarkan jumlah kunjungan sebanyak 3-4 kali berjumlah 7 orang atau 14\% dan terakhir responden berdasarkan jumlah kunjungan sebanyak $>5$ kali berjumlah 13 orang atau $26 \%$.

\section{Hasil Uji Analisis Regresi Berganda}

Uji analisis ini digunakan untuk mengetahui pengaruh variabel independen (bagian luar kafe, interior umum, tata letak kafe dan pajangan interior) terhadap variabel dependen (keputusan pembelian 
Vol. 7, No 1, Januari 2021, 030-038

konsumen). Dalam pengujian ini peneliti akan menganalisa melalui perhitungan pada Tabel dibawah ini:

\begin{tabular}{|c|c|c|c|c|c|}
\hline \multicolumn{6}{|c|}{ Coefficients $^{\mathbf{a}}$} \\
\hline \multirow{2}{*}{ Model } & \multicolumn{2}{|c|}{ Unstandardized Coefficients } & \multirow{2}{*}{$\begin{array}{c}\text { Standardized } \\
\text { Coefficients }\end{array}$} & \multirow{2}{*}{$\mathrm{t}$} & \multirow{2}{*}{ Sig. } \\
\hline & B & Std. Error & & & \\
\hline (Constant) & .486 & .893 & & .543 & .589 \\
\hline $\mathrm{x} 1$ & .512 & .170 & .351 & 3.013 & .004 \\
\hline $\mathrm{x} 2$ & .961 & .211 & .664 & 4.562 & .000 \\
\hline $\mathrm{x} 3$ & -.242 & .119 & -.206 & -2.036 & .048 \\
\hline $\mathrm{x} 4$ & -.383 & .150 & -.358 & -2.542 & .015 \\
\hline R Square & .543 & & & & \\
\hline F Hitung & 13.359 & & & & \\
\hline $\mathrm{a}$ & 0.05 & & & & \\
\hline
\end{tabular}

Sumber : hasil olahan data penelitian

Dari hasil uji regresi pada di atas, dapat diketahui bahwa persamaan regresinya adalah:

$$
Y=0.486+0.512 X_{1}+0.961 X_{2}+\left(-0.242 X_{3}\right)+\left(-0.383 X_{4}\right)
$$

Berdasarkan persamaan regresi berganda diatas, dapat dijelaskan nilai koefisien bagian luar kafe, interior umum, tata letak kafe dan pajangan interior adalah sebagai berikut:

a. Nilai Konstanta sebesar .486 yang memberikan nilai positif artinya bahwa variabel independen (bagian luar kafe, interior umum, tata letak kafe dan pajangan interior) dalam penelitian ini memiliki pengaruh positif terhadap keputusan pembelian konsumen pada Mr. DavCoffee Shop Palu.

b. Nilai koefisien variabel bagian luar kafe $\left(\mathrm{X}_{1}\right)$ sebesar 0.512 , dapat diartikan bahwa untuk setiap pertambahan variabel bagian luar kafe akan menyebabkan meningkatnya proses keputusan pembelian konsumen. Sedangkan variabel lainnya konstan.

c. Nilai koefisien variabel interior umum $\left(\mathrm{X}_{2}\right)$ sebesar 0.961, dapat diartikan bahwa untuk setiap pertambahan variabel interior umum akan menyebabkan meningkatnya proses keputusan pembelian konsumen. Sedangkan variabel lainnya konstan.

d. Nilai koefisien variabel tata letak kafe $\left(\mathrm{X}_{3}\right)$ sebesar -0.242 , dapat diartikan bahwa untuk setiap pertambahan variabel tata letak kafe akan menyebabkan menurunnya keputusan pembelian konsumen. Sedangkan variabel lainnya konstan.

e. Nilai koefisien variabel pajangan interior $\left(\mathrm{X}_{4}\right)$ sebesar -0.383, dapat diartikan bahwa untuk setiap pertambahan variabel pajangan interior akan menyebabkan menurunnya keputusan pembelian konsumen. Sedangkan variabel lainnya konstan. 
Vol. 7, No 1, Januari 2021, 030-038

\section{Pengujian Hipotesis Pertama (Uji Simultan/Uji F)}

Analisis regresi berganda dengan menggunakan uji $\mathrm{F}$ digunakan untuk menguji pengaruh secara serempak terhadap semua variabel. Apabila nilai signifikansi lebih kecil dari $0,05(\operatorname{sig}<0,05)$ maka model regresi signifikan secara statistic. dalam model ANOVA diperoleh nilai sig F yaitu 0,000 yang artinya nilai tersebut lebih kecil jika dibandingkan dengan nilai signifikansi sebesar 0,05 . Dengan demikian dapat disimpulkan bahwa variabel independen secara simultan yang terdiri dari bagian luar kafe, interior umum, tata letak kafe dan pajangan interior berpengaruh terhadap keputusan pembelian konsumen pada Mr. Dav Coffee Shop Palu.

\section{Pengujian Hipotesis Kedua - Kelima (Uji Parsial/Uji t)}

a. Menguji signifikansi Variabel Bagian Luar Kafe $\left(\mathrm{X}_{1}\right)$

Dari tabel diatas terlihat menunjukkan bahwa variabel bagian luar kafe memiliki nilai signifikansi 0.004 yang artinya nilai tersebut lebih kecil dari taraf signifikansi yaitu sebesar 0,05 . Dengan demikian dapat disimpulkan bahwa secara parsial variabel bagian luar kafe berpengaruh signifikan terhadap keputusan pembelian konsumen pada Mr. DavCoffee Shop Palu.

b. Menguji signifikansi Interior $\operatorname{Umum}\left(\mathrm{X}_{2}\right)$

Dari tabel diatas terlihat menunjukkan bahwa variabel interior umum memiliki nilai signifikansi 0.000 yang artinya nilai tersebut lebih kecil dari taraf signifikansi yaitu sebesar 0,05 . Dengan demikian dapat disimpulkan bahwa secara parsial variabel interior umum berpengaruh signifikan terhadap keputusan pembelian konsumen pada Mr. DavCoffee Shop Palu.

c. Menguji signifikansi Tata Letak Kafe $\left(\mathrm{X}_{3}\right)$

Dari tabel diatas terlihat menunjukkan bahwa variabel tata letak kafe memiliki nilai signifikansi 0.048 yang artinya nilai tersebut lebih kecil dari taraf signifikansi yaitu sebesar 0,05 . Dengan demikian dapat disimpulkan bahwa secara parsial variabel tata letak kafe berpengaruh signifikan terhadap keputusan pembelian konsumen pada Mr. DavCoffee Shop Palu.

d. Menguji signifikansi Pajangan Interior $\left(\mathrm{X}_{4}\right)$

Dari tabel diatas terlihat menunjukkan bahwa variabel pajangan interior memiliki nilai signifikansi 0.015 yang artinya nilai tersebut lebih kecil dari taraf signifikansi yaitu sebesar 0,05 . Dengan demikian dapat disimpulkan bahwa secara parsial variabel pajangan interior berpengaruh signifikan terhadap keputusan pembelian konsumen pada Mr. DavCoffee Shop Palu.

\section{Uji Koefisien Determinasi $\left(\mathbf{R}^{2}\right)$}

determinasi $\mathrm{R}^{2}$ yang berasal dari kuadrat $\mathrm{R}$ yaitu $0.737 \mathrm{X} 0.737$ atau senilai $\mathrm{R}_{\text {square }}$ sebesar 0.543 sama dengan 54,3\%. Jika angka koefisien jarak determinasi berkisar antara nol sampai dengan satu $\left(0 \leq \mathrm{R}^{2} \leq 1\right)$ maka $45,7 \%(100 \%-54,3 \%)$ yang tidak dapat dijelaskan oleh persamaan regresi berganda ini. Nilai tersebut berasal dari satu nilai determinasi dikurangi 0.543 atau dapat dinyatakan dalam bentuk presentase sebesar $45,7 \%$. Berdasarkan nilai tersebut dapat memberikan gambaran variabel bagian luar kafe, interior umum, tata letak kafe dan pajangan interior berpengaruh terhadap keputusan pembelian konsumen Mr. DavCoffeeShop Palu. 54,3\% yang dapat dikriteriakan sebagai pengaruh pada tingkat sedang, sisanya $45,7 \%$ dijelaskan pada variabel yang tidak disertakan pada penelitian ini. 


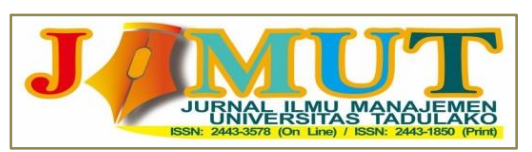

\section{Vol. 7, No 1, Januari 2021, 030-038 \\ 5. KESIMPULAN DAN SARAN \\ Kesimpulan}

Berdasarkan uraian yang dikemukakan tentang pengaruh variabel bagian luar kafe, interior umum, tata letak kafe dan pajangan interior terhadap keputusan pembelian pada Mr. DavCoffee Shop Palu, dapat ditarik kesimpulan sebagai berikut:

a. Dari hasil penelitian terlihat jelas bahwa semua variabel yang terdiri dari bagian luar kafe, interior umum, tata letak kafe dan pajangan interior berpengaruh terhadap keputusan pembelian konsumen pada Mr. DavCoffee Shop Palu.

b. Berdasarkan hasil penelitian bahwa secara parsial variabel bagian luar kafe berpengaruh signifikan terhadap keputusan pembelian konsumen pada Mr. DavCoffee Shop Palu.

c. Berdasarkan hasil penelitian bahwa secara parsial variabel interior umum berpengaruh signifikan terhadap keputusan pembelian konsumen pada Mr. DavCoffee Shop Palu.

d. Berdasarkan hasil penelitian bahwa secara parsial variabel tata letak kafe berpengaruh signifikan terhadap keputusan pembelian konsumen pada Mr. DavCoffee Shop Palu.

e. Berdasarkan hasil penelitian bahwa secara parsial variabel pajangan interior berpengaruh signifikan terhadap keputusan pembelian konsumen pada Mr. DavCoffee Shop Palu.

\section{Saran}

\section{a. Bagi Kafe}

Berdasarkan hasil penelitian dengan variabel suasana toko menjadi penentu keputusan pembelian konsumen pada Mr. DavCoffee Shop Palu sudah terpenuhi secara optimal. Tetapi untuk aspek tata letak kafe dan pajangan interior perlu ditingkatkan lagi pelaksanannya yang dimana kedua variabel tersebut menunjukkan pengaruh negative terhadap keputusan pembelian. Berkaitan dengan hal tersebut diharapkan pihak Mr. Dav Coffee Shop palu perlu meningkatkan penerapan dan pelaksanaan tata letak kafe dan pajangan interior diantaranya penempatan ruangan yang memudahkan konsumen berinteraksi dengan karyawan seperti meja kasir dan juga menyusun pajangan kafe dengan rapi sehingga menjadi daya tarik tersendiri bagi konsumen untuk berkunjung dan melakukan pembelian.

b. Peneliti selanjutnya

Peneliti selanjutnya diharapkan dapat mengembangan penelitian ini dengan meneliti faktor lain yang dapat mempengaruh keputusan pembelian konsumen. Sehingga informasi yang didapatkan lebih bervariasi daripada kuesioner yang jawabannya telah tersedia. Dan juga diharapkan dapat melakukan perbandingan antar suasana toko pada bisnis ritel lainnya sehingga dapat melihat peranan suasana toko terhadap keputusan jika diterapkan dalam bisnis ritel lainnya.

\section{REFERENSI}

Berman, Barry \& Evans, Joel R. (2010). Retail Management (11th ed.) New Jersey: Prentice Hall

Ghozali, Imam. 2013. Aplikasi Analisis Multivariate dengan Program IBM SPSS 21 Update PLS Regresi. Semarang: Badan Penerbit Universitas Diponegoro

Kotler, Philip dan Gary Armstrong. 2001. Prinsip-prinsip Pemasaran. Diterjemahkan oleh: Damos Sihombing, M. B. A. Edisi 8. Jakarta: Erlangga

Kotler, Philip dan Kevin Lane Keller. 2016. Marketing Management. Edition 15. England 
Vol. 7, No 1, Januari 2021, 030-038

Kurniawan, Albert. November 2014. Metode Riset Untuk Ekonomi dan Bisnis. Penerbit: Alfabeta. Bandung

Octaviani, Achirul. 2013. Pengaruh Store Atmosphere Terhadap Keputusan Pembelian Konsumen Coffe Toffe Jatim Expo Surabaya. Jurnal Pendidikan Tata Niaga, Vol.1, No.2

Sugiyono. September 2015. Metode Penelitian Kuantitatif, Kualitatif dan Kombinasi (Mixed Methods). Penerbit: Alfabeta. Bandung

Valentine, Karen. Desember 2014. Pengaruh Store Atmosphere Terhadap Keputusan Pembelian Pada Dakken Coffee \& Steak Bandung. E-Proceeding of Management, Vol.1, No.3

Sumber Internet :

https://id.m.wikipedia.org/wiki/Hipotesis (Tanggal diakses : 17 Desember 2018)

https://id.m.wikipedia.org/wiki/Kafe (Tanggal akses: 1 Desember 2018)

https://www.kalinfo.web.id/2017/02/pengertian-kafe-cafe.html?m=1 (Tanggal akses : 2 November 2018)

https://www.hestanto.web.id/store-atmosphere/ (Tanggal diakses: 2 Januari 2019) 